\title{
On the current and possible future status of the neustonic isopod Idotea metallica Bosc in the North Sea: a laboratory study
}

\author{
Lars Gutow*, Heinz-Dieter Franke \\ Biologische Anstalt Helgoland, Stiftung Alfred-Wegener Institut für Polar- und Meeresforschung, Box 180, D-27483 Helgoland, Germany
}

Received 6 June 2000; accepted 14 September 2000

\begin{abstract}
In the 1990s, a period of extraordinarily mild winter temperatures in the German Bight (North Sea), the oceanic, neustonic isopod Idotea metallica Bosc was found for the first time off the island of Helgoland. The species was recorded in subsequent summer periods, reproducing successfully in the area, while its whereabouts in winter remained uncertain. The question arises whether a continuing increase in mean winter water temperature, as predicted in most scenarios on future climate, might enable I. metallica to overwinter in the North Sea and to become a permanent resident there. Experiments on laboratory-cultured $I$. metallica were performed for the first time. Population dynamics was studied at different temperatures in microcosms. Furthermore, the temperature effects on reproductive output, mortality and duration of embryonic development were studied in individually reared animals. The results suggest that at current temperature conditions (mean winter water temperature of about $5^{\circ} \mathrm{C}$ ) I. metallica is unable to overwinter in the German Bight, and that even an increase to about $8^{\circ} \mathrm{C}$ probably would not change this situation. The recently observed summer populations of the species in the German Bight obviously originate from individuals introduced each year anew by water currents from the Atlantic Ocean. Nevertheless, I. metallica may be useful as a sensitive indicator: in a warming North Sea the species may become a regular summer immigrant, developing more and more conspicuous populations in this area as the annual period with water temperature above the critical level $\left(13^{\circ} \mathrm{C}\right)$ for reproduction extends. (c) 2001 Elsevier Science B.V. All rights reserved.
\end{abstract}

Keywords: Marine isopods; Idotea metallica; Temperature effects; Climatic changes; Immigrations; Population dynamics; North Sea

\section{Introduction}

There is a growing awareness that the earth's thermal regime is changing, whatever the exact reasons may be. Most scenarios predict an increase in global mean temperature of $1.0-3.5^{\circ} \mathrm{C}$ over the next 100 years (IPCC, 1996). Temperature has a pervasive influence on performances at all levels of biological organisation (Hochachka and Somero, 1984). As even minor changes in habitat temperature have significant

\footnotetext{
* Corresponding author.

E-mail address: lgutow@awi-bremerhaven.de (L. Gutow).
}

effects on the distribution and abundance of species, the ecological long-term implications of a possible persistent trend in climatic change have become an issue of increasing interest (e.g. Beukema et al., 1990; Fields et al., 1993; Wood and McDonald, 1997). The impact is expected to be greatest in marine organisms inhabiting the surface layers (neustonic communities) and/or semi-enclosed shelf sea areas.

The annual extremes of a local temperature regime are particularly important in constraining species. The species composition of the North Sea, which is under strong continental influence, is largely determined by winter (rather than summer) temperatures. Many 
oceanic species are apparently excluded from the area by cold winter temperatures (Beukema, 1990; De Vooys, 1990). In the last decade, however, remarkably positive temperature anomalies have been recorded in the North Sea (e.g. Franke et al., 1999). Whether this is a signal of the predicted long-term warming trend, or just a short-term phenomenon, cannot yet be decided. Becker and Pauli (1996) describe temperature anomalies in the North Sea as a rather regular phenomenon with a frequency of about eight years. There is a high temporal correlation between the North Atlantic Oscillation (NAO) index and the occurrence of abnormal water temperatures, suggesting that the latter results from an increased advection of heat from the North Atlantic.

Warming in higher mid latitudes obviously does not result in an equal year-round increase in mean monthly temperatures but it is most marked during the winter months (Beukema, 1992; Franke et al., 1999). A persistent warming trend should allow species constrained by low winter temperatures to extend their ranges into the North Sea while some indigenous species may disappear from the area because they are unable to cope with the altered (physical and/or biological) conditions. There is actually an obvious incidence between the mild winter temperatures in the 1990s and an increasing number of records of oceanic, warm-temperate species in the North Sea (Greve et al., 1996; Edwards et al., 1999).

Permanent populations of the isopod Idotea metallica occur in more or less subtropical areas, suggesting that the species is unable to resist low water temperatures. In 1994, I. metallica was recorded for the first time in the German Bight off the island of Helgoland (Franke et al., 1999). Following a slight increase in population size in 1995, the species disappeared completely from the area after the severe winter of 1995/1996. In 1998 and 1999, however, I. metallica re-occurred in higher numbers than ever before.

The first and only previous records of I. metallica in the North Sea date from the 1970s when two single specimens were reported, one from the Dutch and one from the Norwegian coast (Pethon, 1970; Huijsman and Huwae, 1978). Since Naylor's report (Naylor, 1957) on the occasional occurrence of members of this species off the Western British coasts, the question has been as to how the species reaches North- west Europe and what its status is in the European temperate waters. As the recent appearance of the species in the German Bight relates to a remarkable series of warm winters since 1988, I. metallica may be regarded as a potential immigrant to a warming North Sea.

Collections of surface drift material off Helgoland have only been carried out from spring to autumn and there is, thus, no information available on the species' fate in winter (Franke et al., 1999). Locke and Corey (1989) observed the population dynamics of I. metallica in the Bay of Fundy (Nova Scotia) and found that it does not overwinter in these temperate waters.

In order to evaluate the species' current and possible future status in the North Sea, laboratory experiments were performed for the first time on $I$. metallica. Could a sustained rise in winter temperature enable the species to establish a permanent breeding population in the North Sea in the near future? Or will it remain a (more or less regular) summer visitor disappearing from the area during winter?

\section{Material and methods}

I. metallica shows a neustonic lifestyle, inhabiting the sea surface where it is found associated with drift material such as detached macroalgae (Ascophyllum nodosum, Fucus spp.), timber, remains of fishing nets and plastic waste (Franke et al., 1999). Macroalgal debris and associated small organisms serve as food for this omnivorous species. Copepods, decapod larvae and other small prey items are snatched out of the surrounding water by the first pair of pereiopods. The association with the drift material is important because I. metallica is not a very persistent swimmer.

The passive transport of stable drift material by surface currents results in an almost cosmopolitan distribution of the species. Stable breeding populations are found in the Mediterranean (Dow and Menzies, 1958; Abelló and Frankland, 1997), in the Black Sea (Carausu, 1954) and off the east coast of North America (Naylor, 1957; Locke and Corey, 1989).

The experimental animals were taken from mass cultures maintained since 1994 at the Biologische Anstalt Helgoland (BAH). The original stock 


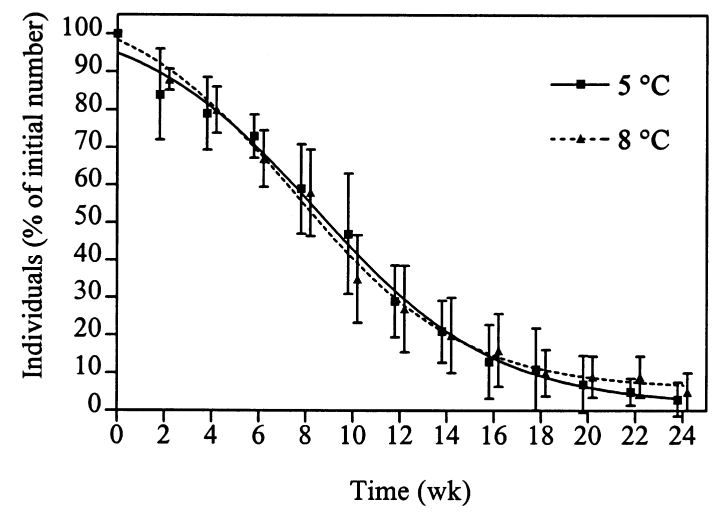

Fig. 1. Dynamics of experimental populations of I. metallica in microcosms at 5 and $8^{\circ} \mathrm{C}$ : five replicates each.

consisted of individuals collected from drift material off Helgoland. Later, individuals collected during several cruises of the BAH research vessel 'Heincke' in the Mediterranean and the Atlantic Ocean were introduced to the cultures. Individuals from different geographic locations were found to reproduce successfully among each other (Franke et al., 1999). The mass cultures are kept under constant conditions $\left(16^{\circ} \mathrm{C}\right.$ and an LD $16: 8$ light-dark regime) in cylindrical $\left(50 \mathrm{dm}^{3}\right)$ plastic tanks. The cultures are run as flow-through systems, permanently supplied with filtered seawater. The animals are fed daily with freshly hatched Artemia nauplii.

\subsection{Microcosm cultures}

The dynamics of the experimental populations of $I$. metallica was studied in aerated $5 \mathrm{dm}^{3}$ microcosms at $5^{\circ} \mathrm{C}$ (current winter water temperature near Helgoland), $8^{\circ} \mathrm{C}$ (possible future winter water temperature predicted by recent warming scenarios) and $16^{\circ} \mathrm{C}$ (current summer water temperature). The microcosms were stocked with 20 animals each (10 juvenile males and 10 juvenile females, about 45 days old) and kept under a constant light/dark regime (LD 16:8).

To each microcosm we added $100 \mathrm{~g}$ of the brown alga Fucus vesiculosus, which served both as food and substratum to cling to. The larvae of Artemia sp. were available ad libitum as an additional source of food. The medium was changed whenever it was considered necessary. For this purpose, the algae and the animals were transferred to a newly prepared microcosm with seawater of the same temperature. Every 14 days, the algae were replaced by new ones and the isopods were counted and classified as 'juveniles' (sexes externally indistinguishable) and 'adults'.

At each temperature, five parallel microcosms (replicates) were run. The experimental period was 24 weeks.

\subsection{Individual cultures}

To obtain data about the mechanisms underlying population dynamics, the reproductive output, the physiological mortality and the duration of embryonic (marsupial) development were studied in individually reared animals. The experimental animals were placed in small glass cups $(\varnothing 6 \mathrm{~cm})$ with $20 \mathrm{~cm}^{3}$ of seawater each, kept at a constant temperature $(5,8,16,18$, and $25^{\circ} \mathrm{C}$ ) and under a constant light/dark regime (LD 16:8).

Each cup was supplied with a small piece of gauze $\left(1-2 \mathrm{~cm}^{2}\right)$ which served as a substratum for the animal to cling to. The medium was changed daily, and Artemia nauplii were offered ad libitum as the only source of food.

Whenever a female was about to molt, a male of the same age was added for about $24 \mathrm{~h}$ for mating. The animals were controlled daily to obtain the relevant data.

\subsection{Data analysis}

Data analyses were performed with the program GraphPad PRISM Version 2.00 (GraphPad Software Incorporated, San Diego, CA, USA, 1995). The rates of decrease in population density at 5 and $8^{\circ} \mathrm{C}$ were compared by Student's t-test. Non-linear regressions were tested to be convenient for the data by GraphPad PRISM's runs-test. Means (number of reproductive cycles and life-time reproductive success) at different temperatures were compared by a one-way analysis of variance (ANOVA) with a successive Tukey's multiple comparisons test.

\section{Results}

\subsection{Population dynamics in microcosms}

At both 5 and $8^{\circ} \mathrm{C}$, no reproduction occurred in the experimental populations. A simple decrease in 
Table 1

Results of the regression analysis following the Boltzmannsigmoid-model and runs-test for the dynamics of experimental populations at 5 and $8^{\circ} \mathrm{C}$ (n.s. $=$ not significant)

\begin{tabular}{lcc}
\hline & $5^{\circ} \mathrm{C}$ & $8^{\circ} \mathrm{C}$ \\
\hline Top & 104.6 & 109.4 \\
Bottom & 1.6 & 5.8 \\
$V_{50}$ & 8.5 & 7.6 \\
Slope & -3.8 & -3.6 \\
df & 61 & 61 \\
$R^{2}$ & 0.93 & 0.95 \\
$P$-value & 0.85 & 0.46 \\
Deviation from the model & n.s. & n.s. \\
\hline
\end{tabular}

density could be observed which followed in a statistically significant way the Boltzmann-sigmoid-model (Fig. 1; Table 1). The curves (\% survivors $Y$ as a function of time $X$ ) are described by the equation

$Y=$ Bottom $+\frac{(\text { Top }- \text { Bottom })}{1+\mathrm{e}^{\left(V_{50}-X\right) / \text { Slope }}}$,

where 'Top' is the initial number of individuals, 'Bottom' the number of individuals at the end of the experimental period and $V_{50}$ the time at which population density is halfway between Top and Bottom. The rate of population decrease was $0.60 \pm 0.06 \%$ per day at $5^{\circ} \mathrm{C}$, and $0.63 \pm 0.15 \%$ per day at $8^{\circ} \mathrm{C}$. The difference is statistically not significant (Student's $t$-test, $P=0.75)$. At both temperatures the populations became almost extinct within 24 weeks.

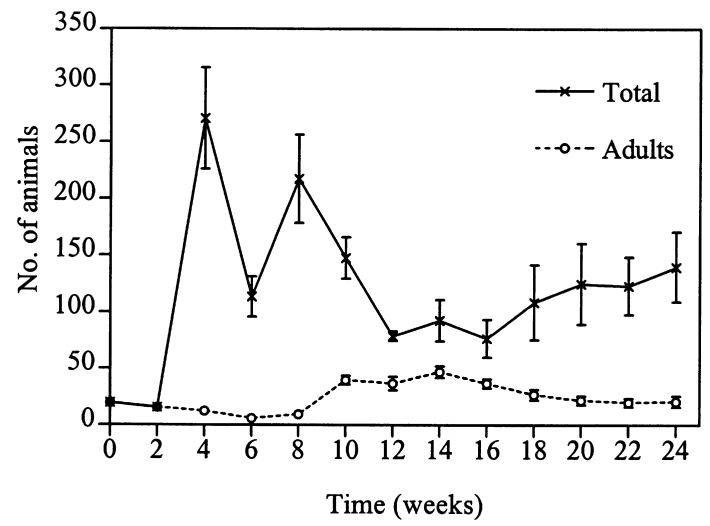

Fig. 2. Dynamics of experimental populations of I. metallica in microcosms at $16^{\circ} \mathrm{C}$ : five replicates.
Table 2

Reproduction (number of reproductive cycles and life-time reproductive success) in female I. metallica kept individually at different temperatures

\begin{tabular}{cccc}
\hline Temperature $\left({ }^{\circ} \mathrm{C}\right)$ & $N$ & $\begin{array}{l}\text { Number of } \\
\text { reproductive } \\
\text { cycles } \\
(\text { mean } \pm \mathrm{SD})\end{array}$ & $\begin{array}{l}\text { Life-time } \\
\text { reproductive } \\
\text { success } \\
(\text { mean } \pm \mathrm{SD})\end{array}$ \\
\hline 5 & 18 & 0 & 0 \\
8 & 20 & 0 & 0 \\
16 & 31 & $0.84 \pm 1.32$ & $32.18 \pm 57.60$ \\
18 & 26 & $1.15 \pm 0.88$ & $32.15 \pm 32.85$ \\
25 & 17 & $3.12 \pm 1.50$ & $47.47 \pm 33.19$ \\
\hline
\end{tabular}

At $16^{\circ} \mathrm{C}$ the population dynamics followed the classical model for continuously reproducing animal populations (Fig. 2). After a period of marked oscillations, the population density approached a specific $K$ (capacity)-value of about 150 individuals (total) and about 25 adults per microcosm.

\subsection{Data from individual cultures}

\subsubsection{Reproductive activity}

The individually reared $I$. metallica were unable to reproduce at winter temperatures $\left(5\right.$ and $\left.8^{\circ} \mathrm{C}\right)$. At 16 , 18 and $25^{\circ} \mathrm{C}$, however, the animals reproduced successfully (Table 2). At $25^{\circ} \mathrm{C}$, the mean number of reproductive cycles per female was significantly

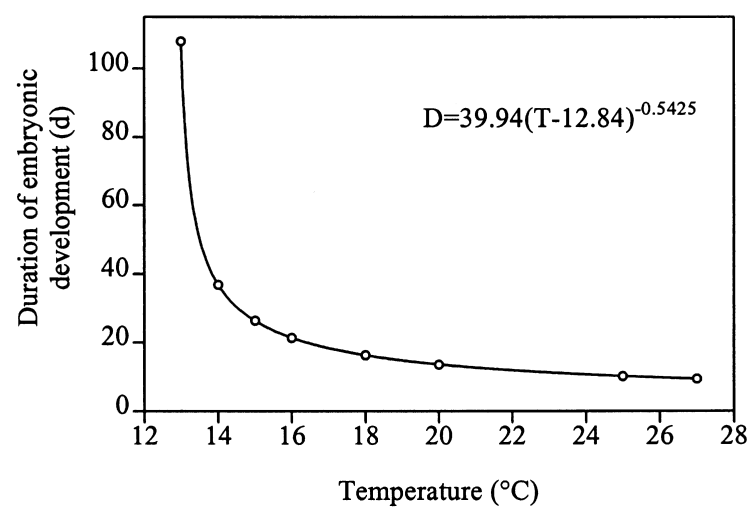

Fig. 3. Duration of embryonic (marsupial) development as a function of temperature. The values for 16,18 and $25^{\circ} \mathrm{C}$ have been measured directly whereas the others have been calculated using Belehrádek's equation. 


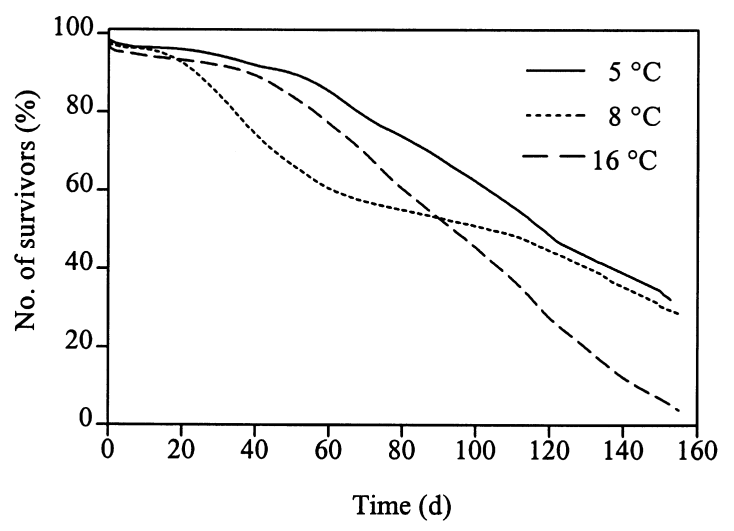

Fig. 4. Survival curves for individually reared I. metallica at 5, 8 and $16^{\circ} \mathrm{C}$.

greater than at $16(P<0.001)$ and $18^{\circ} \mathrm{C}(P<0.001)$. The differences between 16 and $18^{\circ} \mathrm{C}$, however, are statistically not significant $(P>0.05)$. The mean lifetime reproductive success per female was greatest at $25^{\circ} \mathrm{C}$ but, due to high standard deviations, the differences among 16,18 and $25^{\circ} \mathrm{C}$ are statistically not significant $(P=0.47)$.

\subsubsection{Duration of the embryonic (marsupial) development}

From the duration of the embryonic development measured at different temperatures $\left(16,18\right.$ and $\left.25^{\circ} \mathrm{C}\right)$ and by using the equation of Belehrádek (McLaren, 1966), a graph could be calculated showing developmental time ( $D$, in days) as a function of temperature $\left(T\right.$, in $\left.{ }^{\circ} \mathrm{C}\right)$ (Fig. 3). Belehrádek's equation is given by

$D=a(T-\alpha)^{b}$,

where $a, b$ and $\alpha$ are specific constants, for I. metallica amounting to: $a=39.94, b=-0.5425$ and $\alpha=$ 12.84. For low temperatures the curve approaches a vertical asymptote. Its position on the graph's abscissa is identical with the constant $\alpha$ and represents the temperature at which the duration of embryonic development theoretically tends to infinity. A temperature of about $13^{\circ} \mathrm{C}$ may thus be regarded as the critical value below which reproduction in I. metallica is impossible.

\subsubsection{Physiological mortality}

Temperatures of 5 and $8^{\circ} \mathrm{C}$ did not have significantly different effects on the survivorship of young I. metallica (Fig. 4). The number of experimental animals decreased with an average rate of $0.45 \%$ per day at $5^{\circ} \mathrm{C}$ and $0.46 \%$ per day at $8^{\circ} \mathrm{C}$. Assuming the mortality rate is more or less constant over the animals' lifetime, the physiological mortality may be expected to result in a complete extinction of a group of I. metallica within about 220 days at both temperatures.

At $16^{\circ} \mathrm{C}$ the average daily mortality rate was slightly increased and the 'populations' became extinct within about 160 days.

\section{Discussion}

In the microcosms, I. metallica reproduced and developed successfully at $16^{\circ} \mathrm{C}$. This indicates that the species' fundamental niche was realised in the microcosms and that the failure of reproduction at 5 and $8^{\circ} \mathrm{C}$ can definitely be attributed to low temperature. Using the model of Belehrádek, the critical (lower) temperature for reproduction in I. metallica was found to be about $13^{\circ} \mathrm{C}$.

In the German Bight, the sea surface temperature is below $13^{\circ} \mathrm{C}$ for at least eight months (Franke et al., 1999). During this period, a (hypothetical) resident population of I. metallica could only decrease in the number of individuals since reproduction cannot take place. The present laboratory findings on mortality rates cast serious doubt on the ability of a resident population to survive a winter period in the North Sea. The (physiological) mortality rate at 5 and $8^{\circ} \mathrm{C}$ was found to result in complete extinction of a population within about six months (microcosm experiments: mortality in the absence of interspecific constraints) and seven months (individual cultures: mortality in the absence of both inter- and intraspecific constraints), respectively. The difference is probably due to cannibalism in the microcosms, since food was never limiting. Under natural conditions, i.e. when constrained by predators, interspecific competitors, etc., a resident population of I. metallica would surely suffer a considerably higher mortality rate ('ecological mortality') than under the above laboratory conditions. Furthermore, as a sea surface 
dweller, the species may be temporarily exposed to extremely low temperatures even in mild winters. There is no indication that the species abandons the sea surface to advance into deeper layers as does its congener Idotea baltica which is found in both the neustonic and the benthic communities of the shallow coastal waters (Franke and Janke, 1998).

After summer, invertebrates often adapt themselves gradually to the low winter temperatures to limit mortality, e.g. by storing lipids and reducing their activity. Even if I. metallica exhibits such mechanisms of pre-adaptation, a comparison with I. baltica casts serious doubts on the species' capability to overwinter in the North Sea. Relevant experiments (not presented here) were also carried out on this indigenous species revealing significantly lower mortality rates at winter temperatures than in I. metallica. Populations of I. baltica survived an experimental winter period without any pre-adaptation, and even reproduced at $8^{\circ} \mathrm{C}$. This demonstrates that the temperature optima of the two species are quite different and that I. metallica probably lacks the capacity to resist the North Sea winter conditions.

We conclude that I. metallica is unable to overwinter in the North Sea under the current thermal regime, and that even an increase in mean winter water temperature from 5 to $8^{\circ} \mathrm{C}$ probably would not change this situation. Consequently, the summer populations of the species observed off Helgoland in successive years in the 1990s must have derived from individuals introduced into the North Sea each year anew.

As a neustonic organism associated with surface drift material, I. metallica has the potential to spread widely, transported passively by surface water currents. It is likely that in this way small numbers of individuals have always reached the North Sea waters but have usually remained undetected. This is indicated by two chance finds of a single specimen each off the Norwegian and Dutch coasts in the 1970s (Huijsman and Huwae, 1978; Pethon, 1970). However, there is no record of a real population of I. metallica in the North Sea prior to the species' appearance off Helgoland in 1994 (Franke et al., 1999). I. metallica is rather conspicuous with respect to colour and body form. If substantial populations had previously been present in the German Bight (and particularly off Helgoland), this would certainly have been noticed.
Two (probably interrelated) factors may be responsible for the recent appearance of conspicuous populations of I. metallica in the North Sea: (1) In the late 1980s and the 1990s, an exceptional inflow of oceanic water into the North Sea was observed (Lindley et al., 1990; Edwards et al., 1999). Along with drift material, an increased number of I. metallica might have been introduced into the North Sea. (2) Once introduced, individuals of $I$. metallica probably found unprecedentedly suitable conditions for reproduction in a North Sea exhibiting positive temperature anomalies since 1988.

From the above experimental results, we do not expect I. metallica to become a permanent resident in the North Sea in the near future, even if average water temperatures continue to increase. Nevertheless, the species may be a useful indicator of a possible warming trend of the North Sea waters. I. metallica may become a regular summer immigrant developing more and more conspicuous populations if the annual period with water temperatures above the critical level of $13^{\circ} \mathrm{C}$ increases. Our long-term monitoring program (since 1988) on isopods associated with surface drift material will be continued to document possible future changes in the status of I. metallica in the German Bight.

A climatic change in an area is only a precondition for immigration of particular species. Whether a species will actually be able to establish itself in such an area also depends on its ability to prevail against competitors, predators, parasites, etc. Because of a complex interplay between physical and biological factors, direct and indirect effects of temperature changes, the precise consequences of thermal longterm changes for ecosystems are difficult to predict. An analysis of the effects of short-term temperature anomalies such as periods with exceptionally mild winters, however, can give an idea of what may happen in a warming ecosystem (Beukema, 1992). There are good reasons to expect that species richness in the Wadden Sea (and this may also be true of the North Sea as a whole) will increase if the recent trend towards a warmer (winter) climate continues (De Vooys, 1990; Beukema, 1992).

The appearance of a species in an area where it has not been present before can result in a dramatic change in the structure of the established ecosystem. This is well known from the (accidental or intentional) 
introductions of non-indigenous species by man's activities but it may also occur when a species extends its range by natural means of dispersal. In 1989, the siphonophore Muggiaea atlantica invaded the German Bight, probably favoured by an exceptional inflow of oceanic water, and exerted an extreme impact on the plankton dynamics of the local community (Greve, 1994). There is no indication that $I$. metallica might ever exert a significant impact on the North Sea ecosystem. Among the drift material off Helgoland, the species co-occurs with its ecologically similar congener I. baltica. Preliminary experiments have indicated that I. baltica is the superior competitor, driving I. metallica to extinction in mixed-species cultures. Therefore, even if in the course of a possible future warming I. metallica might become a regular element of the North Sea fauna, it will probably remain a relatively rare species, restricted to those (offshore) habitats where it escapes strong competition from I. baltica.

The origin (Northeast America, Mediterranean) of the North Sea population of I. metallica is still unknown. Considering the pattern of surface currents in the Northeast Atlantic, it is likely that the species is transported from North America to the Northwest European coasts by the North Atlantic Drift (Naylor, 1957). Even though the North Atlantic Drift towards Northwest Europe may recently have been weaker than usual and there is evidence of a strong northward shelf edge current (Reid et al., 1998), a Mediterranean origin of I. metallica appears rather unlikely. Water outflow from the Mediterranean into the Atlantic happens at several hundred metres depth and thus cannot be responsible for a transport of neustonic organisms. A genetic analysis is in preparation to solve this problem definitely.

\section{References}

Abelló, P., Frankland, R.J., 1997. Population characteristics of the neustonic isopod Idotea metallica (Crustacea, Isopoda, Idoteidae) in the Western Mediterranean (June 1993). Sci. Mar. 61, 409-414.

Becker, G.A., Pauli, M., 1996. Sea surface temperature changes in the North Sea and their causes. ICES J. Mar. Sci. 53, 887-898.

Beukema, J.J., 1990. Expected effects of changes in winter temperatures on benthic animals living in soft sediments in coastal North Sea areas. In: Beukema, J.J., Wolf, W.J., Brouns, J.J.W.M. (Eds.), Expected Effects of Climatic Change on
Marine Coastal Ecosystems. Developments in Hydrobiology, vol. 57. Kluwer, Dordrecht, pp. 83-92.

Beukema, J.J., 1992. Expected changes in the Wadden Sea benthos in a warmer world: lessons from periods with mild winters. Neth. J. Sea Res. 30, 73-79.

Beukema, J.J., Wolf, W.J., Brouns, J.J.W.M. (Eds.), 1990. Expected Effects of Climatic Change on Marine Coastal Ecosystems Developments in Hydrobiology, vol. 57. Kluwer, Dordrecht.

Carausu, A., 1954. Contributii la studiul isopodelor (Crustacea Malacostraca) Marii Negre (litoralul rominesc si regiunile invecinate). III. Familia Idoteidae. Anal. Stiint. Univ. 'Al. I. Cuza' Din Iasi, Sect. II, vol. 1, pp. 137-216.

De Vooys, C.G.N., 1990. Expected biological effects of long-term changes in temperatures on benthic ecosystems in coastal waters around the Netherlands. In: Beukema, J.J., Wolf, W.J., Brouns, J.J.W.M. (Eds.), Expected Effects of Climatic Change on Marine Coastal Ecosystems. Developments in Hydrobiology, vol. 57. Kluwer, Dordrecht, pp. 77-82.

Dow, T.G., Menzies, R.J., 1958. The pelagic isopod Idotea metallica in the Mediterranean. Pubbl. Staz. Zool. Napoli 30, 330336.

Edwards, M., John, A.W.G., Hunt, H.G., Lindley, J.A., 1999. Exceptional influx of oceanic species into the North Sea late 1997. J. Mar. Biol. Assoc. UK 79, 737-739.

Fields, P., Graham, J.B., Rosenblatt, R., Somero, G.N., 1993. Effects of expected global change on marine faunas. Trends Ecol. Evol. 8, 30-37.

Franke, H.-D., Janke, M., 1998. Mechanisms and consequences of intra- and interspecific interference competition in Idotea baltica (Pallas) and Idotea emarginata (Fabricius) (Crustacea: Isopoda): a laboratory study of possible proximate causes of habitat segregation. J. Exp. Mar. Biol. Ecol. 227, 1-21.

Franke, H.-D., Gutow, L., Janke, M., 1999. The recent arrival of the oceanic isopod Idotea metallica Bosc off Helgoland (German Bight, North Sea): an indication of a warming trend in the North Sea? Helgol. Meeresunters. 52, 347-357.

Greve, W., 1994. The German Bight invasion of Muggiaea atlantica. ICES J. Mar. Sci. 51, 355-358.

Greve, W., Reiners, F., Nast, J., 1996. Biocoenotic changes of the zooplankton in the German Bight: the possible effects of eutrophication and climate. ICES J. Mar. Sci. 53, 951-956.

Hochachka, P.M., Somero, G.N., 1984. Biochemical Adaptation. Princeton University Press, Princeton, NY.

Huijsman, M., Huwae, P., 1978. First record of Idotea metallica Bosc on the Netherlands coast. Zeepaard 38, 121-122.

IPCC (Intergovernmental Panel on Climate Change), 1996. IPCC Second Assessment Report: Climate Change 1995. Cambridge University Press, Cambridge, UK.

Lindley, J.A., Roskell, J., Warner, A.J., Halliday, N.C., Hunt, H.G., John, A.W.G., Jonas, T.D., 1990. Doliolids in the German Bight in 1989: evidence for exceptional inflow into the North Sea. J. Mar. Biol. Assoc. UK 70, 679-682.

Locke, A., Corey, S., 1989. Amphipods, isopods and surface currents: a case for a passive dispersal in the Bay of Fundy, Canada. J. Plankton Res. 11, 419-430.

McLaren, I.A., 1966. Predicting the development rate of copepod eggs. Biol. Bull. 131, 457-469. 
Naylor, E., 1957. The occurrence of Idotea metallica Bosc in British waters. J. Mar. Biol. Assoc. UK 36, 599-602.

Pethon, P., 1970. Two species of Isopoda new to Norway. Zoological Museum of the University of Oslo. Occasional Papers, vol. 1 , pp. 1-3.

Reid, P.C., Planque, B., Edwards, M., 1998. Is observed variability in the long-term results of the Continuous Plankton Recorder survey a response to climate change? Fish. Oceanogr. 7, 282-288.

Wood, C.M., McDonald, D.G., 1997. Global Warming. Implications for Freshwater and Marine Fish. Society for Experimental Biology, Seminar Series 61. Cambridge University Press, Cambridge, UK. 